Athens Journal of History - Volume 7, Issue 3, July 2021 - Pages 185-202

\title{
Weaving the Body Politic: The Role of Textile Production in Athenian Democracy as Expressed by the Function of and

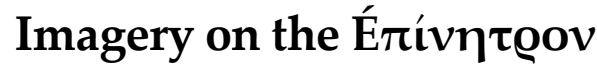

\author{
By Dena Gilby*
}

\begin{abstract}
An examination of the historical and political background of Athens, combined with close readings of several Athenian Ėriv $\eta \tau \alpha$ whose dates span the Late Archaic after the institution of democratic rule and Classical Periods, reveals the possibility that the iconography conveys targeted messages to women consumers - who although perhaps not the purchasers of the Ė $\pi i v \eta \tau \rho \alpha$, are certainly the ones using them - that their their textile contributions to the rólıs (city-state) play a role in the continued success of Athenian democracy.
\end{abstract}

\section{Introduction}

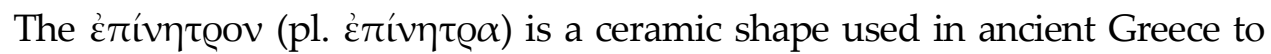
card wool; as such, it is a form created for women (Figure 1). ${ }^{1}$ What can the imagery on these works divulge about the construction of women's contributions in ancient Athens during the period of democratic rule? This presentation

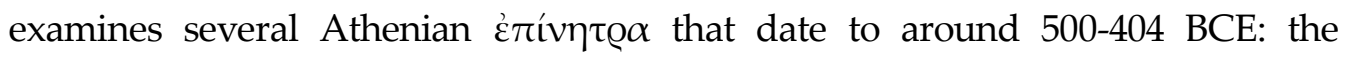
Archaic and Classical periods. At this time the Greeks had already transitioned to democratic rule. It should be noted that the Greek citizen woman could not vote as this was limited to free, citizen men over the age of eighteen. After setting the historical and political background, this paper offers readings of the subject

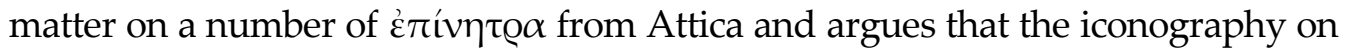
these ceramics conveys messages to its female consumers that their textile production contributes to the health of the Athenian democratic $\pi$ ó $\lambda ı .^{2}$

*Walter J. Manninen Endowed Chair for Art History, Endicott College, USA.

1. John Boardman, "'Reading' Greek Vases?" Oxford Journal of Archaeology 22, no. 1 (2003): 109-114; Andrew J. Clark, Maya Elston and Mary Louise Hart, Understanding Greek Vases: A Guide to Terms, Styles, and Techniques (Los Angeles: J. Paul Getty Museum, 2002); Elizabeth Moignard, Greek Vases: An Introduction (London: Bristol Classical Press, 2012).

2. On ancient Greek democracy see Eric Robinson, Ancient Greek Democracy: Readings and Sources (NY: Wiley \& Sons, 2008) and David L. Stockton, The Classical Athenian Democracy (Oxford: Oxford University Press, 1990). 


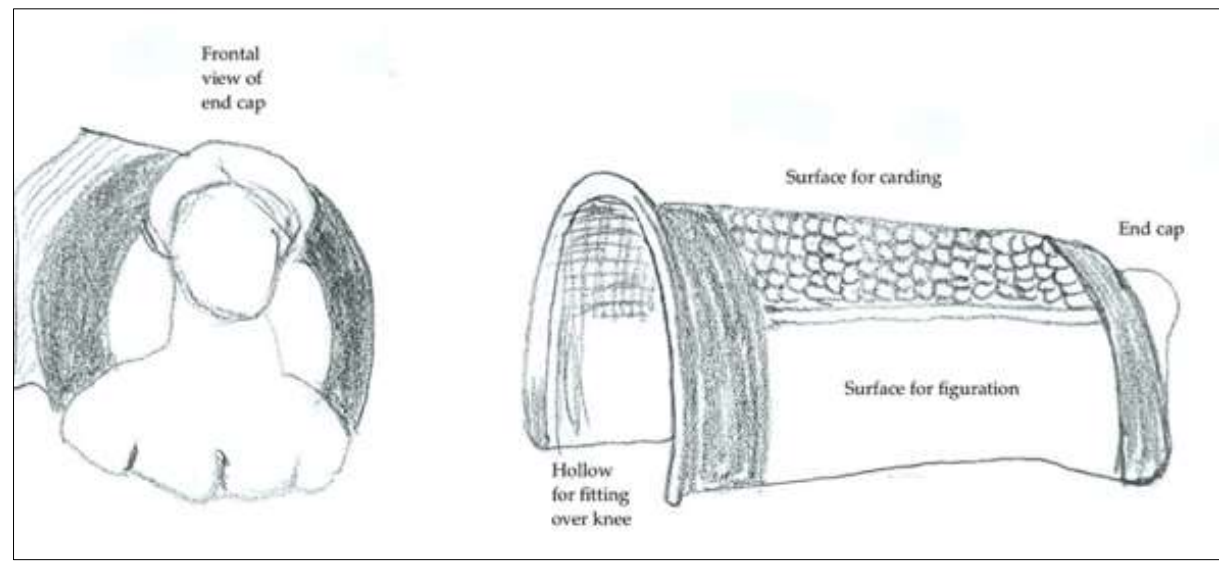

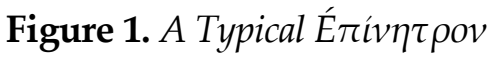

Illustration credit: the author.

\section{A Brief Overview of the Literature and Some Findings}

Compared to such forms as the $\alpha \mu \varphi$ ó $\alpha$ (storage jar) or $\kappa u ́ \lambda_{1} \xi$ (cup), there is a dearth of extant $\dot{\varepsilon} \pi i v \eta \tau \varrho \alpha$ and the literature reflects this in that one of the main concerns is to catalog the examples. ${ }^{3}$ A second major way in which scholars address the vases is within the context of exploring textile production; ; and the third primary inquiry is into individual examples. ${ }^{5}$ There is a consensus that, because there is no functional need for figural imagery, the scenes are a locus of

3. Frauke Heinrich, Das Epinetron. Aspekte der weiblichen Lebenswelt im Spiegel eines Arbeitsgeräts. Internationale Archäologie 93 (Rhaden: Verlag Maria Leidorff, 2006); Chiara Mercati, Epinetron. Storia di una Forma Ceramica fra Archeologia e Cultura (Città di Castello: Petruzzi Editore, 2003).

4. Peter Acton, Poesis: Manufacturing in Classical Athens (Oxford and NY: Oxford University Press, 2014), 147-171; Roger Brock, "The Labour of Women in Classical Athens," The Classical Quarterly, new series 44, no. 2 (1994): 336-346; Irene Good, "Archaeological Textiles: A Review of Current Research," Annual Review of Anthropology 30 (2001): 209-226; Stella Spantidaki, Textile Production in Classical Athens (Oxford: Oxbow Books, 2016).

5. Panayota Badinou, La Laine et Le Parfum: Épinetra et Alabastres, Forme, Iconographie et Fonction (Louvain: Peeters, 2004); Sheramy D. Bundrick, "The Fabric of the City: Imaging Textile Production in Classical Athens," Hesperia 77, no. 2 (2008): 283-334; Sheramy D. Bundrick, "Housewives, Hetairai, and the Ambiguity of Genre in Attic Vase Painting," Phoenix 66, no 1/2 (2012): 11-35; Helga Di Giuseppe, "The Female Pensum in the Archaic and Hellenistic Periods: The Epinetron, the Spindle, and the Distaff," Origini: Preshistory and Protohistory of Ancient Civilizations XL (2017) 259-276; Marina Fischer, "Ancient Greek Prostitutes and the Textile Industry in Attic Vase-Painting ca. 550-450 B.C.E.," The Classical World 106, no. 2 (2013): 219-259; Mary Harlow and Marie-Louise Nosch (Eds.), Greek and Roman Textiles and Dress: An Interdisciplinary Anthology (Oxford and Philadelphia: Oxbow Books, 2014); David M. Robinson, "A New Attic Onos or Epinetron," American Journal of Archaeology 49, no. 4 (1945): 480-490. 
information about cultural, ideological, and political ideals. ${ }^{6}$ What is missing in the literature is a complete, in-depth accounting of one region's or period's vessels. The most comprehensive look at this vase form, worth addressing to get a sense of the importance of Attic manufactured k̇ $\pi_{i} v \eta \tau \propto \alpha$, is that of Chiara Mercati who provides a detailed catalog of extant examples, a treatment of common subjects the the whole corpus, and a number of charts and tables that break down the distribution of both black-figure and red-figure examples. ${ }^{7}$ The provenance table on page 236 of her text catalogs thirty-two black figure and thirteen redfigure examples from Athens with eight of these containing figural scenes; this is the highest number and is followed by the Attic city-state of Brauron with twenty-one black-figure and 20 red-figure, but none of these possess figurative

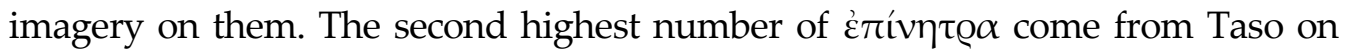
the Aegean Islands with eighteen black-figure, non-figural examples. ${ }^{8}$ One can see from this that Attica is, by far, the most important manufacturing area for this vase type.

\section{Methodology}

The methodology used in this essay is the New Art History defined as:

Something of an umbrella term, embracing elements of *Marxism, * semiotics, and *deconstruction, it is generally used to describe the various approaches to *art history as an intellectual discipline which developed after the Second World War. ${ }^{9}$

The New Art History, in other words, employs a variety of theoretical stances to explore meaning in art; in its current manifestation, multiculturalism, postcolonial studies, and gender studies methodologies, as well as reception theory and object biography, have become the dominant lenses for art historians. ${ }^{10}$ In this essay, therefore, the iconography on each vase is mined using a combination of methodologies derived from semiotics, gender studies, object biography, and reception theory - for its potential to illuminate a

6. Bundrick, Ibid; Fischer, Ibid; Harlow and Nosch, Ibid; Heinrich, Das Epinetron, 2006; Mercati, Epinetron, 2003; Spantidaki, Textile Production, 1-2.

7. Mercati, Epinetron, 233-236.

8. Ibid, 233.

9. Michael Clarke, The Concise Oxford Dictionary of Art Terms (Oxford: Oxford University Press, 2010), 169-170.

10 Anne D'Alleva. Look! Again: Art History and Critical Theory (Upper Saddle River, NJ: Pearson, 2005), 143-149; Jonathan Harris, The New Art History: A Critical Introduction (London and NY: Routledge, 2001), 1-34; Kristina Jõekalda, "What Has Become of the New Art History?" Journal of Art Historiography 9 (December 2013): 1-7. 


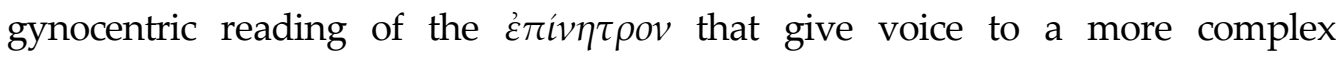
understanding of the multi-faceted meanings that can be derived from visual representations. ${ }^{11}$

\section{Athens and Textile Production: Private and Public}

In regard to the topic of this paper - how women's roles in and contributions

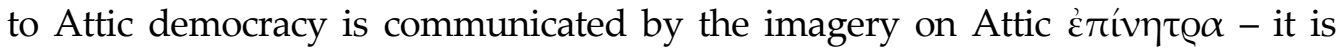
salient to outline the reforms of Cleisthenes at the inception of this political framework. Cleisthenes divided Attica as follows: Athens remained the ä $\sigma \tau v$ (main city-state of a region); it was also one of three partitions of the land. The other two were the $\mu \varepsilon \sigma o ́ \gamma \varepsilon\llcorner o \varsigma$ or $\mu \varepsilon \sigma o ́ \gamma \varepsilon\llcorner\alpha$ (inland) and $\pi \alpha \varrho \alpha \lambda i ́ \alpha$ (coast) sectors. Cleisthenes divided each section into ten groups, each of which is known as a

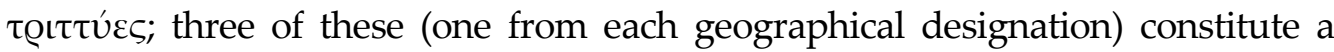
$\varphi v \lambda \eta$ (tribe). Every $\varphi v \lambda \eta$ could be composed of as many as ten smaller entities,

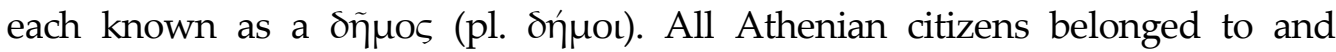
associated their names with a $\delta \tilde{\eta} \mu \mathrm{o}$. This reorganization effectively limited the power wielded by the aristocratic class and distributed the norms of the Athenian ă $\sigma \tau v$ to the whole of Attica. ${ }^{12}$

Textiles were important domestically, within the Tó $ı \varsigma$ (city-state; pl. тó $\lambda \varepsilon เ \varsigma$ ), in the larger Greek world, and beyond. In the oúkos (home) and $\alpha \gamma$ ogó (marketplace), consumers would find a variety of cloaks, robes, tunics, and shirts to adorn both men and women; hairnets and girdles completed women's wear. ${ }^{13}$ As Peter Acton notes, in his book Poesis: Manufacturing in Classical Athens, textile work was not limited to clothing; items related to bed and decorative furnishings, as well as bags, were common household materials; all of which women made and all of which contributed significantly to the well-being and status of those in the oíkos. ${ }^{14}$ Although many of the islands, such as Cyprus, Miletos, and $\pi$ ó $\lambda \varepsilon ı \varsigma$,

11. Chris Gosden and Yvonne Marshall, "The Cultural Biography of Objects," World Archaeology 31, no. 2 (1999): 169-178; Igor Kopytoff, "The Cultural Biography of Things," In The Social Life of Things: Commodities in Cultural Production (ed.) Arjun Appadurai (Cambridge: Cambridge University Press, 1986), 67; Susan Langdon, “Beyond the Grave: Biographies from Early Greece," American Journal of Archaeology 105, no. 4 (2001): 579-606.

12. Ephialtes in 462 BCE and Pericles in 451 BCE completed the reforms in the period of specific concern to this paper. See Pierre Léveque, Pierre Vidal-Naquet and David Ames Curtis, Cleisthenes the Athenian (Atlantic Highlands, NJ: Humanities Press, 1997); Karl-Wilhelm Welwei and Mischa Meier, Athen von den Anfängen bis zum Beginn des Hellenismus (Darmstadt: Darmstadt Primus, 2011).

13. Acton, Poesis, 147-148; Bundrick, "The Fabric of the City," 283-334.

14. Acton, Ibid; Laura McClure, Women in Classical Antiquity from Birth to Death (Hoboken, NJ: Wiley-Blackwell, 2020), 2.3 and 2.4. 
such as Corinth and Megara, were known for their trade in cloth, Athens does not seem to have been a particularly active textile trader. It appears that the focus of textile production for Athens was for domestic and ritual use. ${ }^{15}$

During religious festivals dedications of textiles and production tools are common from very early periods. ${ }^{16}$ Clothing inventories at the Artemis sanctuaries in Brauron and in Athens list textiles. ${ }^{17}$ The most important public festival during the Classical Period in which the Attic Greeks made a textile dedication was the Panathenaic Festival in honor of Athena during which participants offer a $\pi \varepsilon \dot{\varepsilon} \pi \lambda \circ \varsigma$ to the goddess. ${ }^{18}$ In this manner women contributed to the body politic in a very public and far-reaching way..$^{19}$ Moreover, adolescents from aristocratic families aided the priestesses on the first date of the Chalkeia Festival in late October; by the following July the raiment was ready and two adolescent girls from prominent families were chosen to present the garment to Athena at the Greater Panathenaia. ${ }^{20}$ The weaving of and presentation to this goddess is particularly apt because not only is she a goddess of war, but also of handicrafts; serving symbolically as important to both male and female and suggesting that martial and technical productions are both crucial to the success of the city-state. ${ }^{21}$

15. Acton, Ibid; Spantidaki, Textile Production, xxii-xxvii.

16. Cecilie Brøns, Gods and Garments: Textiles in Greek Sanctuaries in the $7^{\text {th }}$ to the $1^{\text {st }}$ Centuries BC (Oxford and Philadelphia: Oxbow Books, 2017); Cecilie Brøns and MarieLouis Nosch, Textiles and Cult in the Ancient Mediterranean (Oxford and Philadelphia: Oxbow Books, 2017).

17. Liza Cleland, The Brauron Clothing Catalogues: Text, Analysis, Glossary and Translation (Oxford: BAR Publishing, 2016); Tullia Linders, Studies in the Treasure Records of Artemis Brauronia Found in Athens (Stockholm: Swedish Institute at Athens, 1972).

18. Brøns, Gods and Garments, 2017; Brøns and Nosch, Textiles and Cult, 2017; Evy Johanne Hắland, "Athena's Peplos: Weaving as a Core Female Activity in Ancient and Modern Greece," Cosmos 20 (2004): 155-182.

19. Matthew Dillon, Girls and Women in Classical Greek Religion (London and NY: Routledge, 2002), 54-60.

20. Herbert William Parke, Festivals of the Athenians (Ithaca: Cornell University Press, 1986); Rosa Reuthner, Wer webte Athenes Gewaïder?: die Arbeit von Frauen im antiken Griechenland (Frankfurt: Campus Verlag, 2006), 296; Noel Robertson, Festivals and Legends: The Formation of Greek Cities in the Light of Public Ritual (Toronto: University of Toronto Press, 1992); John Scheid, Jesper Svenbro and Carol Volk, Le Métier de Zeus. Myth du Tissage et du Tissue dans le Monde Gréco-Romain (Paris: Editions de la Découverte, 1994), 2629; Erika Simon, Festivals of Attica: An Archaeological Commentary (Madison, WI: University of Wisconsin, 2002), 39.

21. Háland, "Athena's Peplos," 155; Parke, Festivals of the Athenians, 1986; Simon, Festivals of Attica, 58-72. 


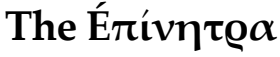

This paper limits the examination of ceramics to those that can be securely placed within manufacture in Attica and that date to the late Archaic and Classical periods; that is, around the beginning of democracy in $508 \mathrm{BCE}$, and its functional end around 404 BCE. As objects used in the production of textiles, which historical evidence both written and material highlight, has not only private but also public visibility (in the form of dedications during civic religious festivals), these objects - as Danielle Smotherman Bennett has aptly observed are "embedding social cues, representing familiar social tasks, and depicting anonymous figures with which women of wide-ranging social statuses could selfidentify" and, thus, can be examined for the pointed messages sent to its consumers. ${ }^{22}$

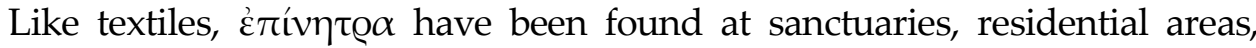
commercial zones, and in graves; all sites that were important in the civic and/or religious life of democratic Attica, making them ideal for the study of their subject matter's relationship to cultural and political messages and meanings. ${ }^{23}$ Mercati offers valuable data about the findspots for $\dot{\pi} \pi i \operatorname{v\eta } \uparrow \alpha$ : sanctuaries are the primary sites, followed by habitation sites, and then cemetaries for those vessels with specified or known findspots. ${ }^{24}$ Mercati, in addition, offers inestimable information about the range of dates for which the greatest numbers of $\dot{\varepsilon} \pi i$ in $\eta \tau \varrho \alpha$ are found that aids in the interpretation of the iconography. Of the black-figure examples, $52.3 \%$ date to the last quarter of the sixth century and first quarter of the fifth century BCE (525-475 BCE); of the red-figure examples, $70.2 \%$ date to the third quarter of the fifth century BCE (450-425 BCE). ${ }^{25}$ One gleans from this that the dates when production was highest corresponds with the waning of Archaic tyranny or clan dominance and the rise and development of democracy.

The figural scenes are varied; they include martial subjects, mythological narrative, as well as imagery centered around activities of the oĩcos. A chronological examination is revelatory about the iconography favored from the

22. Danielle Smotherman Bennett, "Targeted Advertising for Women in Athenian Painting of the Fifth Century BCE," Arts 8, no. 52 (2019): 2; Lauren Hackworth Petersen, "Divided Consciousness and Female Companionship: Reconstructing Female Subjectivity on Greek Vases," Arethusa 30, no. 1 (1997): 35-74; Brunilde Sismondo Ridgway, "Ancient Greek Women and Art: The Material Evidence," American Journal of Archaeology 91, no. 3 (1987): 399-409.

23. Spantidaki, Textile Production, 106-115 offers a listing of textile fragments found in Classical period Attic sites for those interested in the physical examples that help inform the researcher of visual representations of dress.

24. Mercati, Epinetron, 235.

25. Ibid, 236. 
early to the late democracy in Attica. ${ }^{26}$ An early and representative example is now housed in the Metropolitan Museum of Art (Figure 2). Its date places it in the years in which Attica went from dominance by aristocratic clans and, in Athens, from the Peisistratid tyranny to democracy. This black-figure object depicts two four-horse chariots with drivers on each of the long sides and two draped figures, one male and one female, conversing on the end cap. The figural scenes on the long sides suggests, to the viewer familiar with Greek vase painting, that this may illustrate funeral games or the $\dot{\varepsilon} \kappa \varphi \circ \varrho \alpha$ (procession) to the cemetery that took

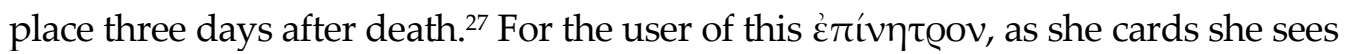
on both sides a reminder of her role in honoring her clan members and contributing to the fame that the deceased (and her clan) receives by preparing the shroud in which he or she will be wrapped; likewise, she will perhaps think of how she will stand in her dark robe around the bier performing mourning rituals at the $\pi \varrho o ́ \sigma \theta \varepsilon \sigma \eta$ (wake) before the body is taken to the cemetary. ${ }^{28}$ Are the figures conversing to be read as mourners discussing the deceased? As the end cap, this would face others in the room while the wool is carded; could this, therefore, broadcast the wool workers' status as contributing member to the clan, to the community as a whole, and to the communal and relational nature of identity in the ancient Greek world? ${ }^{29}$

26. Bennett, "Targeted Advertising," 1-2; John Boardman, The History of Greek Vases: Potters, Painters, and Pictures (London and NY: Thames \& Hudson, 2001), 11; Bundrick, "Housewives, Hetairai, and the Ambiguity," 11-35; Claude Bérard, A City of Images: Iconography and Society in Ancient Greece (Princeton: Princeton University Press, 1989), 89; Mark Stansbury-O'Donnell, Looking at Greek Art (Cambridge and NY: Cambridge University Press, 2011), 170-214; Mark Stansbury-O'Donnell, Elizabeth Langridge-Noti, and Thomas H. Carpenter (Eds.), The Consumers' Choice: Uses of Greek Figure-Decorated Pottery (Boston: Archaeological Institute of America, 2016); Katerina Volioti, "On Show and on the Go: The Advertising Language of Athenian Pottery," Thersites: Journal for Transcultural Presences and Diachronic Identities from Antiquity to Date 6 (2017): 3-42.

27. Ian Morris, "Attitudes toward Death in Archaic Greece," Classical Antiquity 8, no. 2 (1989): 296-320; Lynn E. Roller, "Funeral Games in Greek Art," American Journal of Archaeology 85, no. 2 (1981): 107-119; Peter Toohey, "Death and Burial in the Ancient World," in The Oxford Encyclopedia of Ancient Greece and Rome, volume 1 (Oxford: Oxford University Press, 2010), 364.

28. Maureen Carroll and Jane Rempel, Living through the Dead: Burial and Commemoration in the Classical World (Oxford: Oxbow Books, 2011); Milette Gaifman, The Art of Libation in Classical Athens (New Haven: Yale University Press, 2018); Sarah Iles Johnston, Restless Dead: Encounters between the Living and the Dead in Ancient Greece (Berkeley: University of California Press, 2013); Morris, Ibid; Roller, Ibid; Toohey, Ibid.

29. Jonathan M. Hall, A History of the Archaic Greek World. Second Edition (Malden, MA: Wiley-Blackwell, 2014), 220-226, 238-243, 290-293; Susan Lape, Race and Citizen Identity in the Classical Athenian Democracy (Cambridge and NY: Cambridge University Press, 2010), 82-94, 155-161. 

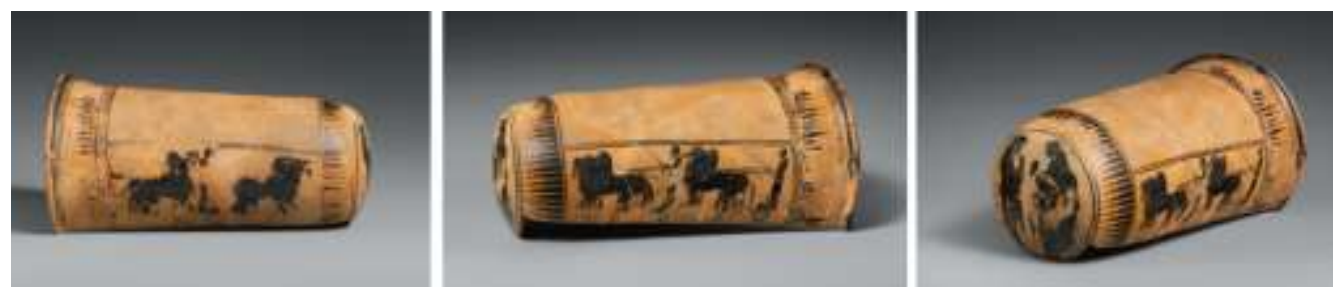

Figure 2. Epinetron, c. 525-500 BCE. Terracotta, l. 11 9/16" (29.4 cm.). Metropolitan Museum of Art, New York (06.1021.52)

Photo credit: Metropolitan Museum of Art, Open Access.

This imagery is not unusual for this era of transition from tyrannical to

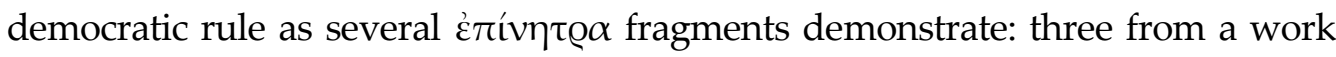
that represents an Amazonomachy and come from the Sanctuary at Eleusis (Eleusis Museum 465); two from the Sanctuary of Artemis at (Brauron Museum A21 and A22) that depict an Amazonomachy and procession on horseback; one from the Athenian agora (American School of Classical Studies, Athens P 16745) that portrays a woman working wool; and one from the Acropolis of Athens (Athens National Museum 2611) that depicts Eos running toward her son, the fallen Memnon, who is identified by inscription. What unites these figural scenes is the signifiers of the life of the aristocratic clans directly through scenes of rituals, rites, and social activities and of their ideals indirectly through mythological narratives. The indirect resonances can be attached to the tendency of Greek makers, from the earliest manifestations to employ myths as metaphors. ${ }^{30}$ The scenes of Greek heroes and heroines, the Amazonomachies, or the gods vanquishing mortals who have transgressed normative behavior speak to makers visually transmitting the behaviors that mortal should either emulate or avoid to conform to the cultural values esteemed among the society. ${ }^{31}$

Three late black-figure paintings date to the early years of the democracy and are, hence, paradigmatic of the transition of subject matter from before and after the fall of the Peisistratids and the institution of democracy. ${ }^{32}$ The Diosphos Painter's work (Figure 3), now housed in the Louvre Museum, portrays on side A a scene of women working wool and displays on side B a frieze of Amazons; the end cap possesses a protome (three-dimensional rendering) of a female head. Side A would be facing the inside thigh of the wool worker while Side B faces outward toward observers so that they see the Amazons. How would the women in the room; that is, the one working the wool and others, interpret this scene? I suggest the possibility that the woman working sees her industry resonating with that of the figural scene closest to her view which, in turn, amplifies her sense that

30. Richard T. Neer, Greek Art and Archaeology c. 1500-c. 150 BCE (NY: Thames \& Hudson, 2012), 204-208; Robin Osborne, Archaic and Classical Greek Art (Oxford and NY: Oxford University Press, 1998), 87-110, 189, 237-242.

31. Neer, Ibid, 204-208; Osborne, Ibid.

32. Bennett, “Targeted Advertising," 1-2, 4, 7. 
her work is important to the functioning of the household (and beyond). On the other hand, the scene facing outward reminds both worker and other women in the room that, although the Amazons were powerful and independent, the Greek patriarchy did vanquish them. Perhaps it is a warning, therefore, to not inflate themselves so much that they lose sight of the ultimate authority: the male head of household his relatives, and the male citizenry. Even so, could a woman read this scene as signifying that textile production holds true power because when the

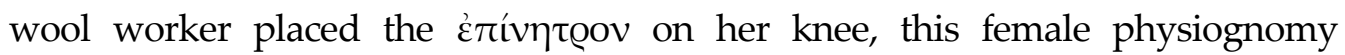
(portrayed in an idealizing mode of representation) would face out, broadcasting that the woman working was an ideal participant in the body politic by creating the textiles needed for home, city, and region.

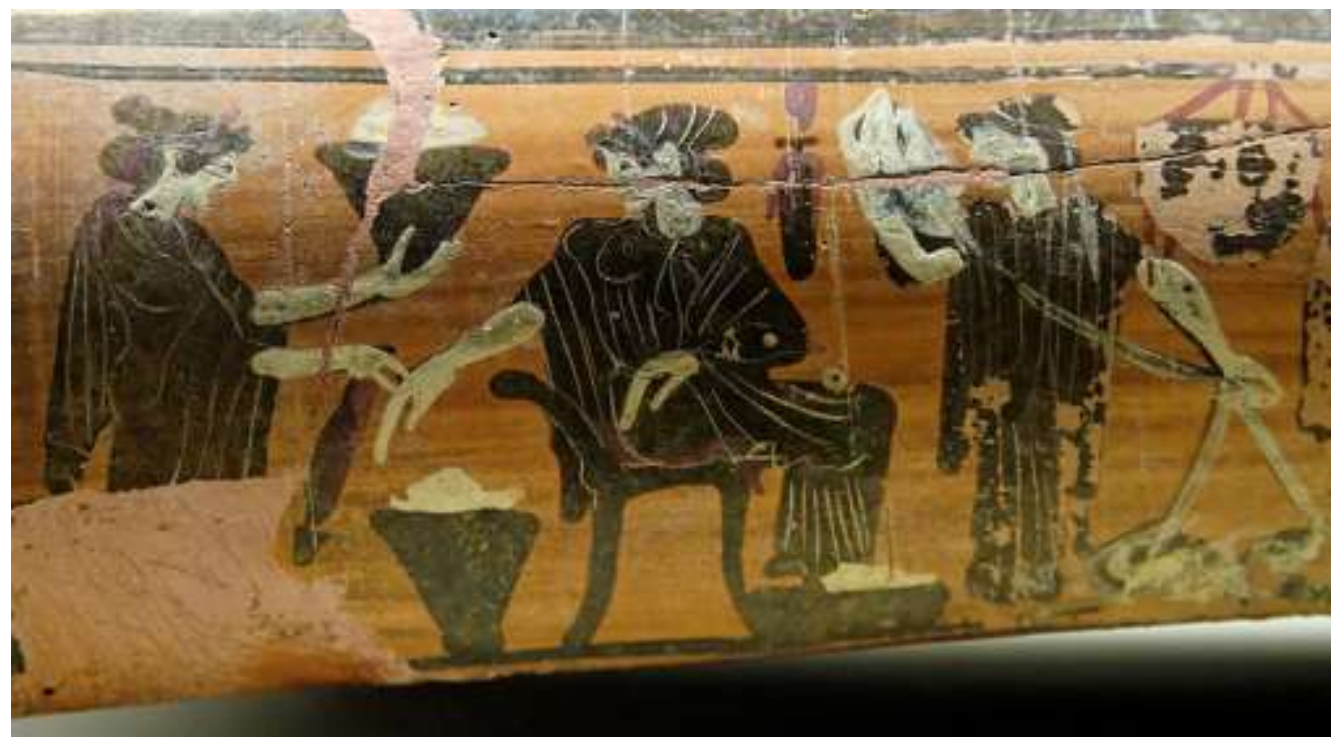

Figure 3. Diosphos Painter, Epinetron, c. 500 BCE. Terracotta, h. 5.4"(13.8 cm.) x l.12.4" (31.5 cm.). Louvre Museum, Paris (MNC 624)

Photo credit: Wikimedia Commons, Marie-Lan Nguyen, Attribution-ShareAlike 2.5 Generic (CC BY-SA 2.5).

The vessel by the Golonos Group (Figure 4) - now located in the British Museum - features figural scenes on both of the long sides that is similar to that of end cap of the Metropolitan vessel (Figure 2): male and female figures

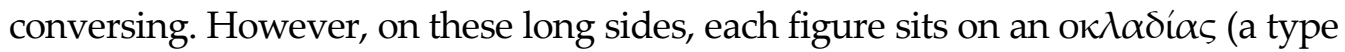
of seat commonly found in domestic settings) in front of hanging textiles, and the end cap consists of a protome consists of a female head. ${ }^{33}$ Some context on the Golonos Group may assist to some degree in interpreting the iconography. This

33. Françoise Frontisi-Ducroux, "Images Grecques du Féminin: Tendances Actuelles de 1'Interprétation," Clio 19 (2004): 135-147; Hélène Guiraud, "La Vie Quotidienne des Femmes a Athènes: A Propos de Vases Attiques du Ve Siècle," Pallas no. 32 (1985): 41-57; Petersen, "Divided Consciousness," 35-74. 
group of anonymous Attic painters attributed by John Beazley, employed the black-figure technique and specialized in the creation of $\dot{\varepsilon} \pi i v \eta \tau \rho \alpha$ using a Late Archaic style; their products date to c. 500-480 BCE and are found beyond the borders of Attica. ${ }^{34}$ The vases had to appeal to a broad array of buyers, therefore, generic imagery that consumers could project a range of significations upon was favored over more specifically "Greek" imagery. Indeed, when searching "Golonos Group" on the Beazley archive seventeen images appear: nine are attributed to the Golonos Group; seven Akin to the Golonos group; and one to the Leagros group. Of the nine attributed directly to the group, eight are fragments of

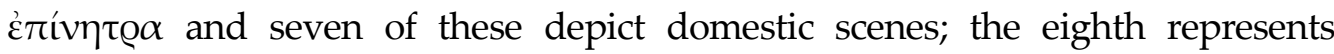
Amazons arming. The ninth work is a fragment of a stand that portrays Artemis

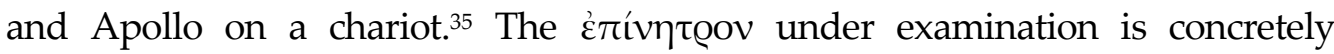
secured to the most popular Golonos group subject and, I would argue, should be interpreted within the context of gender and group identity within early democratic Attica. The men have come into the women's space, as evidenced by the stools and hanging textiles on the wall; would a woman read this as ceding authority to her, or at least recognizing the contributions of women to the household through their textile work?

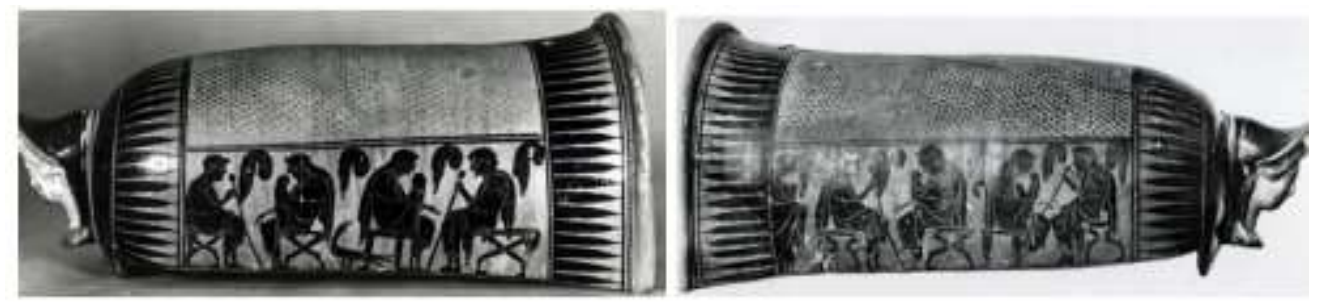

Figure 4. Golonos Group, Epinetron, c. 500 BCE. Terracotta, h. 5.5" (13.95 cm.) x dia. 7.7" (19.65 cm.). British Museum, London (1877,0805.6)

Photo credit: British Museum, Attribution-NonCommercial-ShareAlike 4.0 International (CC BY-NC-SA 4.0).

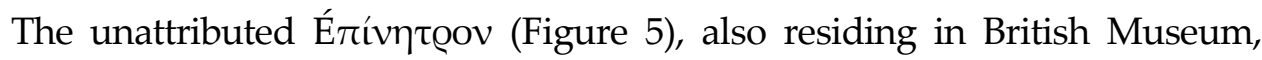
represents on long side A: a $\sigma u \mu \pi$ ó sets: Dionysos - recognized by his ivy-wreath reclines on a $k \lambda$ ív $\eta$ (bed or, in this instance, dining couch). He is turned to the left, conversing with Ariadne, who is

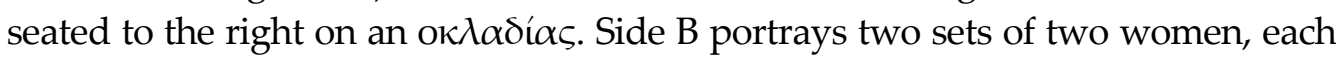

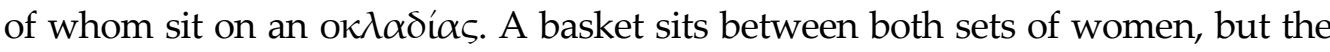
pair positioned to the left in the composition engage is slightly different activities than the pair positioned to the right; they all appear to be engaged in stages of textile work though. At left, one woman lifts the lid of the basket while the other

34. John Beazley, Attic Black Figure Vase Painters (Oxford: Clarendon, 1956), 480.

35. University of Oxford Classical Art Research Centre, "Golonos Group," in Beazley Archive Database. Retrieved from: http://tiny.cc/beazleyarchive. [Accessed 25 February 2021.] 
reaches in; whereas, at right one woman pulls wool while the other raises her arm. Garments hang behind them on the wall, and the end cap consists of a protome of a female head like that on the Golonos Group version. ${ }^{36}$ And like the Golonos Group's protome, this one too looks out at the entire room to broadcast the accomplishments of the industrious textile producing woman.
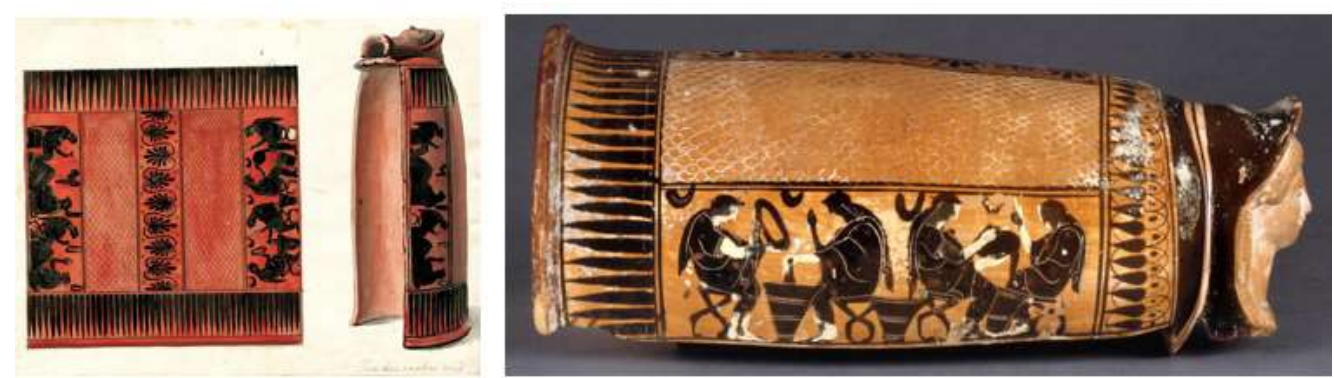

Figure 5. Epinetron, c. 500-480 BCE. Terracotta, h. 4.6" (11.7 cm.) x l. 12.2" (31.10 cm.). British Museum, London (1814,0704.1205)

Photo credit: British Museum, Attribution-NonCommercial-ShareAlike 4.0 International (CC BY-NC-SA 4.0).

The interpretive field of Side A, as demonstrated in discussion of the other vessels treated in this paper thus far, is similar. This is the figural scene closest to the woman carding and she may see herself reflected by it. Although it may appear strange that a narrative relating to the elite-male banquet appears on Side B there are possibilities for the significations consumers might glean from the narrative: 1) women, who ran the household, were undoubtedly responsible for organizing the events, including choosing the pots that would be showcased at them so maybe women saw in the Ariadne figure a surrogate for themselves; 2) before Ariadne became Dionysos' consort, she aided Theseus to defeat the Minotaur and escape the labyrinth by giving him thread to use as a guide so seeing her dining with Dionysos to whom she became the consort implies that women who excel with textiles like Ariadne and aid the male protagonist will be rewarded handsomly; 3) Dionysos was not only the god of wine, but wine featured prominently at the $\pi \varepsilon$ Qísı $\pi v 0 v$ (post-funeral banquet) in honor of the deceased; additionally, wine was among the gifts brought to the gravesite on the third, ninth, thirtieth, and annual anniversary of the death of the individual so his presence in the imagery could be associated with the woman wool worker with that context ${ }^{37}$; and 4) women had primary authority of preparing the body including washing it, making the funeral shroud and any other textiles needed, as

36. Bennett, “Targeted Advertising," 13-19.

37. Carroll and Rempel, Living Through the Dead: Burial and Commemoration in the Classical World, 2011; Gaifman, The Art of Libation in Classical Athens, 2018; Johnston, Restless Dead: Encounters Between the Living and the Dead in Ancient Greece, 2013; Morris, "Attitudes Toward Death," 296-320. 
well as enacting various mourning activities in their dark woven robes. ${ }^{38}$ Thus,

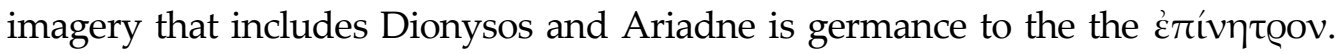
Furthermore, by echoing the composition of side A on side $\mathrm{B}$, the painter has drawn an implicit parallel between the two. Finally, there is the female head protome whose signification has been discussed above for the two works that are in the British Museum.

The trend toward domestic subjects expands and becomes the primary iconography during the art historical shift from the Archaic-Early Classical to the High Classical periods; the titular vase (Figure 6) of the Painter of Berlin 2624, now housed in the Antikensammlung of the State Museums of Berlin, is an

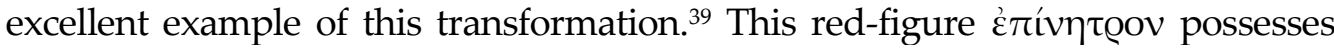
on the long sides scenes of a seated woman between two youths; the woman holds out an $\dot{\alpha} \lambda \alpha \dot{\alpha} \alpha \sigma \tau$ t@ov and the youth facing her proffers a sack. The end cap presents a painted head of a woman. Other works of the era; notably, Athens National Museum 2180 exhibit subject matter so similar as to justify naming this a trope of the High Classical period. ${ }^{40}$ What are the significations that ceramics' female consumers might glean from this trope? I have argued above that, seeing their activities reflected back at them as they carded wool recognized the important role of textile production in the Attic world and would, therefore, send the message to women that their contributions were valuable by equating them with other consumer activities. Furthermore, this scene could speak to not only elite women as Mark Stansbury-O'Donnell has hypothesized. He submits as evidence an غ̇ंívnt@ov that depicts an exchange - prostitute and client negotiating price for services - the textiles on the walls indicate the pair are in a

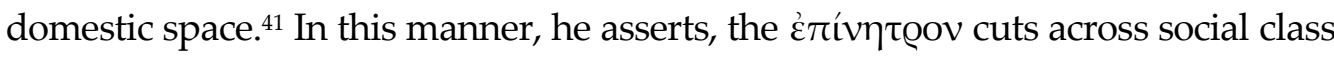
to speak to multiple classes of women in the Greek environment.

38. Dillon, Girls and Women in Classical Greek Religion, 268-292; Kerri J. Hame, "Female Control of Funeral Rites in Greek Tragedy: Klytaimestra, Medea, and Antigone," Classical Philology 103, no. 1 (2008): 1-15.

39. Mercati, Epinetron, XXIII-XXVI and XXVIII.

40. See Mercati, Ibid, XXII-XXX for many instances of this imagery presented in almost identical ways.

41. Mark Stansbury-O'Donnell, A History of Greek Art (Malden, MA: Wiley Blackwell, 2015), 339. See also, Bundrick, "The Fabric of the City," 288-289; Gloria Ferrari, Figures of Speech: Men and Maidens in Ancient Greece (Chicago: University of Chicago Press, 2002), 3560; Mireille M. Lee, Body, Dress, and Identity in Ancient Greece (Cambridge and NY: Cambridge University Press, 2015), 91; Sian Lewis, The Athenian Woman: An Iconographic Handbook (London and NY: Routledge, 2002), 62. 


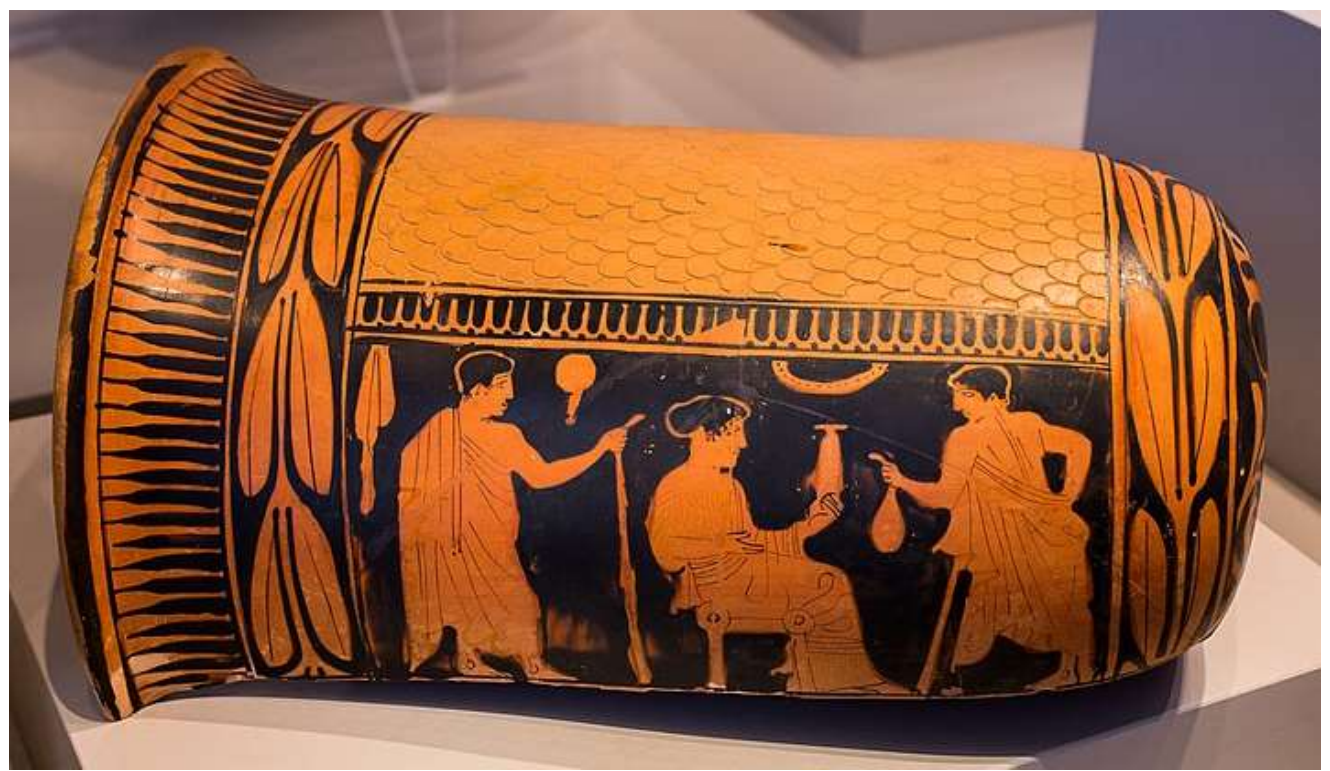

Figure 6. Painter of Berlin 2624, Epinetron, c. 450 BCE. Terracotta, dia. 7.09" (18 cm.) x l. 10.6" (27 cm.). Antikensammlung, State Museums in Berlin - Prussian Cultural Heritage, Berlin (F2624)

Photo credit: Antikensammlung, State Museums in Berlin, Attribution-NonCommercialShareAlike 4.0 International (CC BY-NC-SA 4.0).

Athens National Museum 2179 (Figure 7) is a characteristic example of how

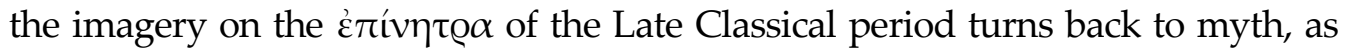
well as to scenes of ritual activity, because the ceramic depicts a scene of maenads on the long sides; the end cap is decorated with a painting of Bellerophon defeating the Chimera while riding Pegasus. ${ }^{42}$ What might women make of these narratives? The maenads are ardent followers of Dionysos whose association with women has been noted, so women could see their ritual activities emphasized, activities that are women-only and hint at some forms of women's agency within the social sphere outside of the home. ${ }^{43}$ Whereas, the presentation of Bellerophon is more perplexing; he is a famous Corinthian, rather than Athenian, hero whose signification concerns being brought down by v́ßeıs (excessive pride or self-confidence). ${ }^{44}$ It seems the maker is warning the consumer of the limits of mortals. This object was produced during the Peloponnesian War; this is an obvious allusion to the civil war, the forces of chaos presented by nondemocratic peoples. I advocate for the idea that women would, perhaps, read

42. Other exampes of this turn to the mythical can be found in Mercati, Epinetron, plates XXIX-XXXV and XXXVII-XL.

43. Cornelia Isler-Kerényi and Anna Beerens, Dionysos in Classical Athens: An Understanding through Images (Leiden: Brill, 2015).

44. Mark Cartwright, "Bellerophon," in World History Encyclopedia. Published 27 March 2020. Retrieved from: https://www.ancient.eu/Bellerophon/. [Accessed 25 February 2021.] 
their production of textiles as their contribution to the war effort for they clothed the soldiers, but the textiles also could be sold to obtain necessities for the fighters; additionally, they would see the wayward figures: Amazons, fantastical beasts, and even maenads as warnings for them not to step out of their approved gender roles.

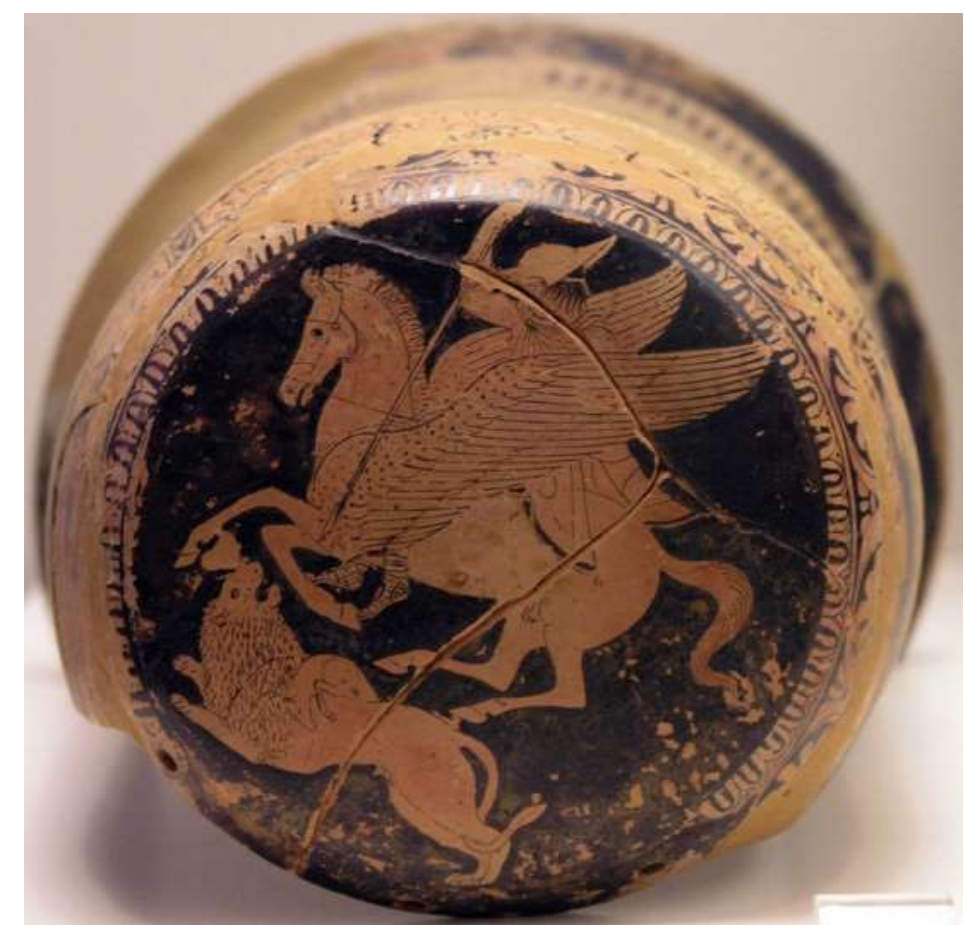

Figure 7. Epinetron, c. 425-420 BCE. Terracotta, l. 10.24" (26 cm.). Athens National Museum, Athens (2179)

Photo Credit: Wikimedia Commons, Marsyas, Attribution-ShareAlike 2.5 Generic (CC BYSA 2.5).

\section{Conclusion}

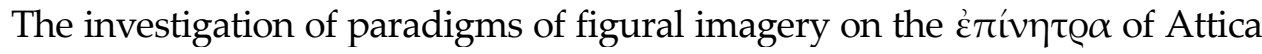
produced from the beginning of democracy to its developed state has illuminated that the iconography can be read on multiple levels: simultaneously. On the one hand, domestic scenes of women working and/or performing social or ritual acts are positive messages to women that their textile productions contribute to the

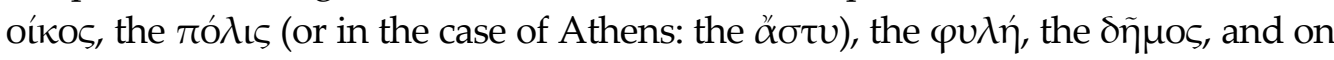
to the of entirety of Attica; on the other hand, the visual narratives of defeated Amazons, Chimera, and other figures are cautionary tale of consequences of transgressing normative gender roles and societal expectations. 


\section{Bibliography}

Acton, Peter. Poesis: Manufacturing in Classical Athens. Oxford and NY: Oxford University Press, 2014.

Badinou, Panayota. La Laine et Le Parfum: Épinetra et Alabastres, Forme, Iconographie et Fonction. (Wool and Perfume: Épinetra and Alabastres, Form, Iconography and Function.) Louvain: Peeters, 2004.

Beazley, John. Attic Black Figure Vase Painters. Oxford: Clarendon, 1956.

Bennett, Danielle Smotherman. "Targeted Advertising for Women in Athenian VasePainting of the Fifth Century BCE." Arts 8, no. 2 (2019): 24 pages.

Bérard, Claude. A City of Images: Iconography and Society in Ancient Greece. Princeton: Princeton University Press, 1989.

Boardman, John. The History of Greek Vases: Potters, Painters, and Pictures. London and NY: Thames \& Hudson, 2001.

. “'Reading' Greek Vases?” Oxford Journal of Archaeology 22, no. 1 (2003): 109-114.

Brock, Roger. "The Labour of Women in Classical Athens." The Classical Quarterly, New Series 44, no. 2 (1994): 336-346.

Brøns, Cecilie. Gods and Garments: Textiles in Greek Sanctuaries in the $7^{\text {th }}$ to the $1^{\text {st }}$ Centuries BC. Oxford and Philadelphia: Oxbow Books, 2017.

Brøns, Cecilie and Marie-Louis Nosch. Textiles and Cult in the Ancient Mediterranean. Oxford and Philadelphia: Oxbow Books, 2017.

Bundrick, Sheramy D. "The Fabric of the City: Imaging Textile Production in Classical Athens." Hesperia 77, no. 2 (2008): 283-334.

. "Housewives, Hetairai, and the Ambiguity of Genre in Attic Vase Painting." Phoenix 66, no 1/2 (2012): 11-35.

Carroll, Maureen and Jane Rempel. Living through the Dead: Burial and Commemoration in the Classical World. Oxford: Oxbow Books, 2011.

Cartwright, Mark. "Bellerophon." In World History Encyclopedia. Published 21 October 2012. Retrieved from: https://www.ancient.eu/Bellerophon/. [Accessed 25 February 2021.]

Clark, Andrew J., Maya Elston and Mary Louise Hart. Understanding Greek Vases: A Guide to Terms, Styles, and Techniques. Los Angeles: J. Paul Getty Museum, 2002.

Clarke, Micheal. The Concise Oxford Dictionary of Art Terms. Oxford: Oxford University Press, 2010.

Cleland, Liza. The Brauron Clothing Catalogues: Text, Analysis, Glossary and Translation. Oxford: BAR Publishing, 2016.

D'Alleva, Anne. Look! Again: Art History and Critical Theory. Upper Saddle River, NJ: Pearson, 2005.

Di Giuseppe, Helga. "The Female Pensum in the Archaic and Hellenistic Periods: The Epinetron, the Spindle, and the Distaff." Origini: Prehistory and Protohistory of Ancient Civilizations XL (2017): 259-276.

Dillon, Matthew. Girls and Women in Classical Greek Religion. London and NY: Routledge, 2002.

Ferrari, Gloria. Figures of Speech: Men and Maidens in Ancient Greece. Chicago: University of Chicago Press, 2002.

Fischer, Marina. "Ancient Greek Prostitutes and the Textile Industry in Attic VasePainting ca. 550-450 B.C.E." The Classical World 106, no. 2 (2013): 219-259. 
Frontisi-Ducroux, Françoise. "Images Grecques du Féminin: Tendances Actuelles de l'Interprétation." Clio 19 (2004): 135-147.

Gaifman, Milette. The Art of Libation in Classical Athens. New Haven: Yale University Press, 2018.

Good, Irene. "Archaeological Textiles: Review of Current Research." Annual Review of Anthropology 30 (2001): 209-226.

Gosden, Chris and Yvonne Marshall. "The Cultural Biography of Objects." World Archaeology 31, no. 2 (1999): 169-178.

Guiraud, Hélène. "La Vie Quotidienne des Femmes a Athènes: A Propos de Vases Attiques du Ve Siècle." (Women's Daily Life in Athens: About $5^{\text {th }}$ Century Attic Vases.) Pallas, no. 32 (1985): 41-57.

Háland, Evy Johanne. "Athena's Peplos: Weaving as a Core Female Activity in Ancient and Modern Greece." Cosmos 20 (2004): 155-182.

Hall, Jonathan M. A History of the Archaic Greek World. Second Edition. Malden, MA: Wiley-Blackwell, 2014.

Hame, Kerri J. “Female Control of Funeral Rites in Greek Tragedy: Klytaimestra, Medea, and Antigone." Classical Philology 103, no. 1 (2008): 1-15.

Harlow, Mary and Marie-Louise Nosch (Eds). Greek and Roman Textiles and Dress: An Interdisciplinary Anthology. Oxford and Philadelphia: Oxbow Books, 2014.

Harris, Jonathan. The New Art History: A Critical Introduction. London and NY: Routledge, 2001.

Heinrich, Frauke. Das Epinetron. Aspekte der weiblichen Lebenswelt im Spiegel eines Arbeitsgeräts. Internationale Archäologie 93. (The Epinetron. Aspects of the Female World in the Mirror of a Work Tool. International Archeology 93.) Rhaden: Verlag Maria Leidorff, 2006.

Isler-Kerényi, Cornelia and Anna Beerens. Dionysos in Classical Athens: An Understanding through Images. Leiden: Brill, 2015.

Jõekalda, Kristina. "What Has Become of the New Art History?" Journal of Art Historiography 9 (December 2013): 1-7.

Johnston, Sarah Iles. Restless Dead: Encounters between the Living and the Dead in Ancient Greece. Berkeley: University of California Press, 2013.

Kopytoff, Igor. "The Cultural Biography of Things." In The Social Life of Things: Commodities in Cultural Production, edited by Arjun Appadurai, 64-91. Cambridge: Cambridge University Press, 1986.

Langdon, Susan. "Beyond the Grave: Biographies from Early Greece." American Journal of Archaeology 105, no. 4 (2001): 579-606.

Lape, Susan. Race and Citizen Identity in the Classical Athenian Democracy. Cambridge and NY: Cambridge University Press, 2010.

Lee, Mireille M. Body, Dress, and Identity in Ancient Greece. Cambridge and NY: Cambridge University Press, 2015.

Lévêque, Pierre, Pierre Vidal-Naquet and David Ames Curtis. Cleisthenes the Athenian. Atlantic Highlands, NJ: Humanities Press, 1997.

Lewis, Sian. The Athenian Woman: An Iconographic Handbook. London and NY: Routledge, 2002.

Linders, Tullia. Studies in the Treasure Records of Artemis Brauronia Found in Athens. Stockholm: Swedish Institute at Athens, 1972. 
McClure, Laura. Women in Classical Antiquity from Birth to Death. Hoboken, NJ: WileyBlackwell, 2020.

Mercati, Chiara. Epinetron. Storia di una Forma Ceramica fra Archeologia e Cultura. (Epinetron. History of a Ceramic Form between Archeology and Culture.) Città di Castello: Petruzzi Editore, 2003.

Moignard, Elizabeth. Greek Vases: An Introduction. London: Bristol Classical Press, 2012.

Morris, Ian. “Attitudes toward Death in Archaic Greece." Classical Antiquity 8, no. 2 (1989): 296-320.

Neer, Richard T. Greek Art and Archaeology c. 1500-c. 150 BCE. NY: Thames \& Hudson, 2012.

Osborne, Robin. Archaic and Classical Greek Art. Oxford and NY: Oxford University Press, 1998.

Parke, Herbert William. The Festivals of the Athenians. Ithaca: Cornell University Press, 1986.

Petersen, Lauren Hackworth. "Divided Consciousness and Female Companionship: Reconstructing Female Subjectivity on Greek Vases." Arethusa 30, no. 1 (1997): 35-74.

Reuthner, Rosa. Wer webte Athenes Gewänder?: die Arbeit von Frauen im antiken Griechenland. (Who Weaved Athene's Robe?: The Labor of Women in Ancient Greece.) Frankfurt: Campus Verlag, 2006.

Ridgway, Brunilde Sismondo. "Ancient Greek Women and Art: The Material Evidence." American Journal of Archaeology 91, no. 3 (1987): 399-409.

Robertson, Noel. Festivals and Legends: The Formation of Greek Cities in the Light of Public Ritual. Toronto: University of Toronto Press, 1992.

Robinson, David M. "A New Attic Onos or Epinetron." American Journal of Archaeology 49, no. 4 (1945): 480-490.

Robinson, Eric. Ancient Greek Democracy: Readings and Sources. NY: Wiley \& Sons, 2008.

Roller, Lynn E. "Funeral Games in Greek Art." American Journal of Archaeology 85, no. 2 (1981): 107-119.

Scheid, John, Jesper Svenbro and Carol Volk. Le Métier de Zeus. Myth du Tissage et du Tissue dans le Monde Gréco-Romain. (The Profession of Zeus. Myth of Weaving and Fabric in the Greco-Roman World.) Paris: Editions de la Découverte, 1994.

Simon, Erika. Festivals of Attica: An Archaeological Commentary. Madison, WI: University of Wisconsin Press, 2002.

Spantidaki, Stella. Textile Production in Classical Athens. Oxford and Philadelphia: Oxbow Book, 2016.

Stansbury-O'Donnell, Mark D. A History of Greek Art. Malden, MA: Wiley Blackwell, 2015. . Looking at Greek Art. Cambridge and NY: Cambridge University Press, 2011.

Stansbury-O'Donnell, Mark, Elizabeth Langridge-Noti and Thomas H. Carpenter (Eds.) The Consumers' Choice: Uses of Greek Figure-Decorated Pottery. Boston: Archaeological Institute of America, 2016.

Stockton, David L. The Classical Athenian Democracy. Oxford: Oxford University Press, 1990.

Toohey, Peter. "Death and Burial in the Ancient World." In The Oxford Encyclopedia of Ancient Greece and Rome, volume 1. Oxford: Oxford University Press, 2010.

University of Oxford Classical Art Research Centre. "Golonos Group." In Beazley Archive Database. Retrieved from: http://tiny.cc/beazleyarchive. [Accessed 25 February 2021.] 
Volioti, Katerina. "On Show and on the Go: The Advertising Language of Athenian Pottery." Thersites: Journal for Transcultural Presences and Diachronic Identities from Antiquity to Date 6 (2017): 3-42.

Welwei, Karl-Wilhelm and Mischa Meier. Athen von den Anfängen bis zum Beginn des Hellenismus. [Athens from the beginning to the beginning of Hellenism.] Darmstadt: Darmstadt Primus, 2011. 